\title{
Safety alert for hospital environments and health professional: chlorhexidine is ineffective for coronavirus
}

Darcelo Souza de Assis ${ }^{1}$

Renata Alves de Andrade Moreira Araújo,

(iD) Angela Maria Moed Lopes ${ }^{1,2}$

1. Masters in Health Management Sciences - Must University, Boca Raton, FL, USA. 2. Capstone Course - Must University, Boca Raton, FL, USA.

http://dx.doi.org/10.1590/1806-9282.66.S2.124

\section{SUMMARY}

An alarming fact was revealed by recent publications concerning disinfectants: chlorhexidine digluconate is ineffective for disinfecting surfaces contaminated by the new coronavirus. This is a finding that requires immediate disclosure since this substance is widely used for the disinfection of hands and forearms of surgeons and auxiliaries and in the antisepsis of patients in minimally invasive procedures commonly performed in hospital environments. The objective of this study is to compare the different disinfectants used for disinfection on several surfaces, in a review of worldwide works. Scientific studies were researched in the BVS (Virtual Health Library), PubMed, Medline, and ANVISA (National Health Surveillance Agency) databases. The following agents were studied: alcohol 62-71\%, hydrogen peroxide $0.5 \%$, sodium hypochlorite $0.1 \%$, benzalkonium chloride $0.05-0.2 \%$, povidone-iodine $10 \%$, and chlorhexidine digluconate 0.02\%, on metal, aluminum, wood, paper, glass, plastic, PVC, silicone, latex (gloves), disposable gowns, ceramic, and Teflon surfaces. Studies have shown that chlorhexidine digluconate is ineffective for inactivating some coronavirus subtypes, suggesting that it is also ineffective to the new coronavirus.

KEYWORDS: Coronavirus. Disinfection. Asepsis. Chlorhexidine.

\section{INTRODUCTION}

COVID-19 is a pandemic caused by a new coronavirus, Sars-CoV-2, which, by 28 May $2020^{1}$, had affected approximately 5,593,631 patients throughout the world, having been the cause of 353,334 deaths (https://www.who.int/docs/default-source/coronaviruse/situation-reports/20200528-COVID-19-sitrep-9. pdf?sfvrsn=5b154880_2 $)^{2}$.

The exponential growth of the novel coronavirus resulted in the halting of the world economy.
According to the United Nations Industrial Development Organization (UNIDO), the world is experiencing the greatest challenge of the post-war era due to the sudden stoppage of economic activity in developed and developing countries. The latest forecasts by the World Trade Organization (WTO) expect a global contraction of around $9 \%$ of the world economy ${ }^{3}$.

Other pandemic outbreaks have happened before, including the Spanish flu (1917-1919), which killed 
between 50 and 100 million people ${ }^{4}$, and the black plague, which struck Europe between 1347 and 1352 and that, according to Alfani and Murphy ${ }^{5}$, was the worst plague of all times, killing between one- and twothirds of the European population and also affecting the north of Africa and most of Asia.

The coronaviruses comprise a large family of viruses, common in humans and some animals, such as camels, oxen, cats, and bats ${ }^{6}$. The most recent pandemic was caused by Sars-CoV-2, which, in its most severe presentation, causes severe acute respiratory failure. This pandemic began in December 2019, in the city of Wuhan, in the Chinese province of Hubei. It spread quickly through China and, soon after, worldwide. In March 2020, the World Health Organization (WHO) recognized the situation as a "pandemic" that, as defined by the entity, is a disease outbreak with a number of cases above the expected, affecting several countries and continents ${ }^{7}$.

One of the factors that may be related to the rapid spread of the novel coronavirus is its great resistance to external environments, unlike other viruses, which are inactivated in seconds, which makes it a challenge regarding strategies of disinfection or adequate antisepsis ${ }^{8}$.

Asepsis, antisepsis, and disinfection have different goals. Asepsis is the set of measures that we use to prevent the penetration of microorganisms in an environment that does not have them, i.e., which is free of infection. Antisepsis is the set of measures proposed to inhibit the growth of microorganisms or remove them from a particular environment, destroying them or not. Disinfection is the process of destroying microorganisms, pathogens or not, occurring in surfaces and objects by applying germicidal agents, classified as disinfectants?.

In practice, the terms antiseptics and disinfectants are used as synonyms; however, they are characterized as antiseptics when used in living tissues, such as the skin and mucous membranes, and as disinfectants when used on inanimate objects, such as metals, wood, and latex'.

Concern about the use of proper antiseptics and disinfectants is related to the health and safety of the people on the frontline of the pandemic. In this context, given the absence of a vaccine against Sars-CoV-2 and of effective treatments for the most acute stages of COVID-19, prevention and antisepsis measures, based on the use of effective disinfecting agents, according to the field of activity, are fundamental to control the dissemination of the disease.
Thus, this review aims to alert health authorities, health professionals, life maintenance agents, such as nurses, pharmacists, biomedicine professionals, paramedics, firefighters, police officers, among others, regarding the inefficiency of chlorhexidine digluconate against the new coronavirus and the need to use appropriate antisepsis and disinfection agents at a large scale.

\section{SARS-COV-2}

According to the Pan American Health Organization (PAHO), seven human coronaviruses (HCoVs) have been identified: HCoV-229E, HCoV-OC43, HCoV-NL63, HCoV-HKU1, Sars-CoV (which causes severe acute respiratory syndrome), Mers-Cov (which causes the Middle Middle East respiratory syndrome), and, most recently, the novel coronavirus (which at first was temporarily called 2019-nCoV and, on 11 February 2020, received the name of Sars-CoV-2), which is responsible for causing the COVID-19 disease ${ }^{10}$.

The coronavíruses belong to the Coronaviridae family and are responsible for a variety of diseases in man and animals, affecting, in particular, the respiratory system. They are composed of single-stranded, positive-sense RNA, containing from 26 to 32 kilobases, and are associated with proteins, forming a nucleocapsid. Its particles present projections on their envelope shaped like spicules, formed by $S$ protein (Spike protein) trimers. These projections look like a crown, hence the name coronavirus ${ }^{\mathbf{1 0 . 1 1}}$ (Figure 1).

Sars-CoV-2 is transmitted mainly by respiratory droplets and has an incubation period of about 4-5 days before the onset of symptoms, which include

FIGURE 1. MOLECULAR STRUCTURE OF THE NOVEL CORONAVIRUS (SARS-COV-2).

\section{Coronavirus}

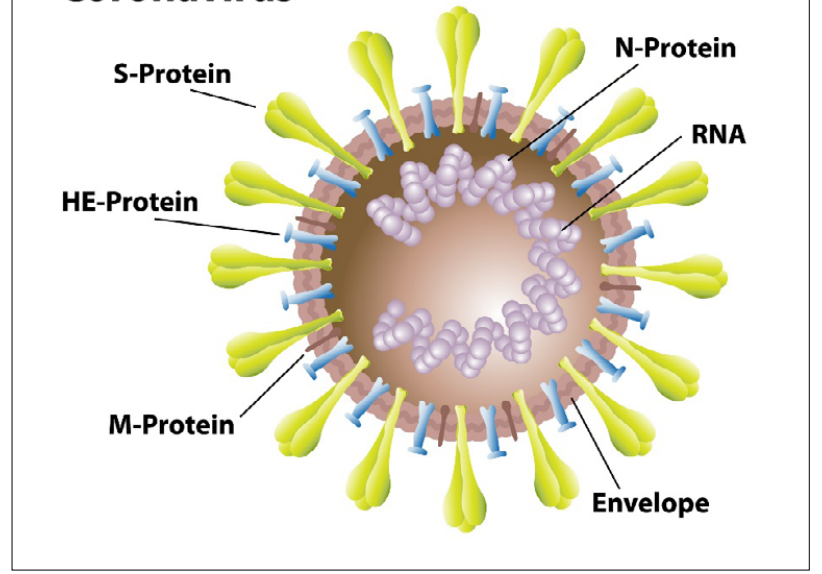

Source: Shutterstock (license number 1684060378). 
fever, cough, breathing difficulties, headaches, muscle and/or joint pain, diarrhea, and nausea. In more severe cases, COVID-19 patients develop acute respiratory distress syndrome (ARDS). The severity of the disease is related not only to the viral infection but also to the host's response, who may succumb to other underlying comorbidities ${ }^{12}$.

Some studies have shown that the human coronaviruses are very resistant outside a host and may remain active on various surfaces for up to nine days ${ }^{8}$, which may explain the effectiveness of contagion and the unbridled spread of the novel coronavirus. According to a study published by Doremalen and collaborators ${ }^{13}$, Sars-CoV-2 viruses have been detected in up to 72 hours after their application in plastic and stainless steel.

\section{GERMICIDES USED AGAINST THE CORONAVIRUS}

According to Geller, Varbanov, and Duval (2012) ${ }^{14}$, a good germicide is considered effective as a disinfectant and antiseptic if it can induce, in well-defined contact time, a reduction in viral titers greater than 3 or $4 \log _{10}$ depending on the American and European regulatory agencies.

The sensitivity of HCoV 229E, a subtype of human coronavirus, to the action of antiseptic disinfectants was evaluated in a study published by Sattar and collaborators ${ }^{15}$ which validated disinfecting agents that reduced viral titers of $3 \log _{10}$ after exposure for $1 \mathrm{~min}$ ute (Table 1).

Table 1 shows that chlorhexidine alone, associated to

TABLE 1. ANTISEPTIC AND DISINFECTANT AGENTS THAT WORK AGAINST THE HCOV (HUMAN CORONAVIRUS).

\begin{tabular}{l|l|l}
$\begin{array}{l}\text { Tested disinfectant anti- } \\
\text { septics }\end{array}$ & Concentration & $\begin{array}{l}\text { Reduction } \\
\text { of the viral } \\
\text { titer } \geq 3 \mathrm{log} \\
\text { after } 1 \mathrm{~min}\end{array}$ \\
\hline Sodium hypochlorite & $0.10 \%$ and $0.50 \%$ & YES \\
\hline Chloramine-T & $0.10 \%$ and $0.30 \%$ & YES \\
\hline $\begin{array}{l}\text { Sodium hypochlorite/ } \\
\text { Potassium bromide }\end{array}$ & $0.05 \%$ and $0.10 \%$ & YES \\
\hline Povidone-iodine & $10 \%$ & YES \\
\hline Ethanol & $70 \%$ & YES \\
\hline Glutaraldehyde & $2 \%$ & YES \\
\hline Chlorhexidine + Cetrimide & $0.008 \%+0.08 \%$ & NO \\
\hline $\begin{array}{l}\text { Chlorhexidine + Cetrimide }+ \\
\text { Ethanol }\end{array}$ & $0.05 \%+0.5 \%+$ & YES \\
\hline Source:Adapted from Sattar and $0 \%$ & \\
\hline
\end{tabular}

cetrimide or associated to less than $70 \%$ ethanol, which is widely used in medicine, is ineffective against the HCOV 229E, one of the lightest variants of the coronavirus, since reaches only 0.008-0.8 $\log _{10}$ of inactivation, except when associated with $70 \%$ ethanol ${ }^{15}$.

The biocidal agent chlorhexidine is widely used in hospitals for antisepsis of cutaneous and mucosal surfaces in the antisepsis of the hands and forearms of surgeons and asepsis and antisepsis of surgical patients or patients undergoing invasive and minimally invasive procedures, such as peripheral punctures, placement of catheters, vesical tubes, drains, central venous catheters, and tracheostomies, all common procedures in patients admitted to intensive care units (ICUs) ${ }^{16}$.

TABLE 2. PERSISTENCE OF THE CORONAVIRUS IN DIFFERENT INANIMATE SURFACES.

\begin{tabular}{|c|c|c|c|c|}
\hline Surfaces & Virus & $\begin{array}{l}\text { Inoc- } \\
\text { ulum } \\
\text { (viral } \\
\text { titer) }\end{array}$ & Temperature & $\begin{array}{l}\text { Per- } \\
\text { sistence }\end{array}$ \\
\hline Steel & MERS-CoV & 105 & 200 to $30^{\circ} \mathrm{C}$ & $\begin{array}{l}8 \mathrm{~h} \text { to } \\
48 \mathrm{~h}\end{array}$ \\
\hline Aluminum & $\mathrm{HCoV}$ & $5 \times 103$ & $210 C$ & $2-8 h$ \\
\hline Metal & SARS-CoV & 105 & Room temp. & 5 days \\
\hline Wood & SARS-CoV & 105 & Room temp. & 4 days \\
\hline Paper & SARS-CoV & 105 & Room temp. & 4-5 days \\
\hline Glass & $\begin{array}{l}\text { SARS-CoV } \\
\text { HCoV }\end{array}$ & $\begin{array}{l}105 \\
103 \\
\end{array}$ & $\begin{array}{l}\text { Room temp. } \\
210 \mathrm{C}\end{array}$ & $\begin{array}{l}4 \text { days } \\
5 \text { days }\end{array}$ \\
\hline Plastic & $\begin{array}{l}\text { SARS-CoV } \\
\text { MERS-CoV }\end{array}$ & $\begin{array}{l}105 \\
105 \\
\end{array}$ & $\begin{array}{l}220 \text { to } 250 \mathrm{C} \\
20^{\circ} \mathrm{C}\end{array}$ & $\begin{array}{l}\leq 5 \text { days } \\
48 \mathrm{~h}\end{array}$ \\
\hline PVC & $\mathrm{HCoV}$ & 103 & 210 & 5 days \\
\hline Silicone & $\mathrm{HCoV}$ & 103 & 210 & 5 days \\
\hline Gloves (latex) & $\mathrm{HCoV}$ & $5 \times 103$ & 210 & $8 \mathrm{~h}$ \\
\hline $\begin{array}{l}\text { Disposable } \\
\text { apron }\end{array}$ & SARS-CoV & 106 & Room temp. & 2 days \\
\hline
\end{tabular}

Source: Adapted from Sattar and colleagues (2020) 8.

TABLE 3. INACTIVATION OF THE CORONAVIRUS BY DIFFERENT DISINFECTANTS.

\begin{tabular}{l|l|l|l|l} 
Biocidal Agent & $\begin{array}{l}\text { Con- } \\
\text { cen- } \\
\text { tration }\end{array}$ & Virus & $\begin{array}{l}\text { Expo- } \\
\text { sure } \\
\text { Time }\end{array}$ & $\begin{array}{l}\text { Reduction } \\
\text { of viral } \\
\text { activity } \\
\text { (log10) }\end{array}$ \\
\hline Ethanol & $70 \%$ & MHV & 10 min. & $\geq 3.9$ \\
\hline $\begin{array}{l}\text { Sodium hypo- } \\
\text { chlorite }\end{array}$ & $0.21 \%$ & MHV & $30 \mathrm{~s}$ & $\geq 4.0$ \\
\hline $\begin{array}{l}\text { Hydrogen peroxide } \\
\text { Povidone-iodine }\end{array}$ & $0.5 \%$ & HCoV & $1 \mathrm{~min}$. & $>4$ \\
\hline $\begin{array}{l}\text { Glutaraldehyde } \\
0.23 \%\end{array}$ & $2.0 \%$ & SARS-CoV & $15 \mathrm{~s}$ & $\geq 4.4$ \\
$15 \mathrm{~s}$ & $\geq 4.4$ \\
\hline $\begin{array}{l}\text { Chlorhexidine } \\
\text { gluconate }\end{array}$ & $0.02 \%$ & MHV & $10 \mathrm{~min}$. & $>3$ \\
\hline
\end{tabular}

Source: Adapted from Sattar and colleagues (2020) 8. 
They are usually used at a concentration of $0.5 \%$ and may be associated with antiseptic solutions, aqueous or alcoholic, and are excellent germicides, according to Moriya and Modena ${ }^{9}$. This is the option of choice against gram-positive bacteria, but its action is ineffective for the coronavirus family ${ }^{9.16}$.

According to Colares $(2015)^{17}$, the microbicidal activity of chlorhexidine is mainly against gram-positive and gram-negative vegetative bacteria. It does not act on sporulating forms, except at high temperatures. Some lipophilic viruses, such as influenza, herpes virus, and HIV, are quickly inactivated.

Another study that is very relevant to this topic was conducted by the University of Medicine of Greifswald, Germany. It described the persistence of various strains of coronavirus, including Sars$\mathrm{CoV}$, Mers-CoV, and $\mathrm{HCoV}$, on different surfaces. The authors demonstrated that these variants of the coronavirus can persist on inanimate surfaces, such as metal, glass, or plastic for between two hours and nine days ${ }^{8}$.

In addition, this study also described the action of some disinfectant agents, including alcohol 70\%, hydrogen peroxide $0.5 \%$, sodium hypochlorite $0.1 \%$, benzalkonium hydrochloride $0.05-0.2 \%$, povidone-iodine $10 \%$, and $0.02 \%$ chlorhexidine digluconate, comparing the inactivity of the several strains mentioned in several inanimate surfaces, such as metal, aluminum, paper, glass, plastic, PVC, silicone, latex (gloves), disposable aprons, ceramics, and Teflon (Table 2). In this table, it is possible to observe that certain strains of coronaviruses are capable of resisting up to five days on metal, paper, glass, plastic, PVC, and silicone surfaces ${ }^{8}$.

The data in Table 3 are even more alarming, because they demonstrate that chlorhexidine reduces the titer of the MHV virus, a murine strain of the coronavirus, only in 0.7-0.8 $\log _{10}$, and the standard level established by international bodies is $\geq 3 \log _{10}$ of inactivation in 1 minute of exposure ${ }^{8}$.

The study by Koh (2020) demonstrates a great increase of cases of COVID-19 infections among health professionals, making this a high-risk group. From 138 cases of patients treated at the Hospital of Wuhan, 40 (29\%) were health professionals. Among those affected, $31(77 \%)$ worked in general activities, seven (17.5\%) in the emergency room, and two (5\%) in the ICU ${ }^{18}$.

The Federal Nursing Council (COFEN) (2020) published that already over 10,000 nurses, technicians, and nursing assistants have been removed from work due to COVID-19 in Brasil, with 88 deaths by May 2020. According to the Council, this figure is more than double than that of contaminated professionals in Italy (http://www.cofen.gov.br/cofen-publica-observatorio-diario-da-COVID-19-entre-profissionais-de-enfermagem_79551.html ${ }^{19}$. However, to date, no study has assessed the possible association between the use of chlorhexidine as a disinfection agent as a possible cause of dissemination of the novel coronavirus among health professionals, but this could be a potential factor for greater infection due to its inefficiency in inactivating the virus.

\section{PROTECTIVE AND ANTISEPSIS MEASURES AGAINST THE NOVEL CORONAVIRUS}

The Regional Council of Pharmacy of Minas Gerais created a booklet called PADM - Protocol for Antisepsis of Massive Disinfection in response to the novel coronavirus; we suggest its adoption as complementary care for the protection of the population and mainly of healthcare professionals who are at the frontline of the pandemic ${ }^{20}$.

The PADM includes actions of antisepsis of the hands and forearms to eliminate a possible viral load; lips, tongue, and mucous membranes of the oral cavity; nostrils and oropharyngeal mucosa; eyeballs and lacrimal ducts; and dermis and mucosae of infected and hospitalized. The booklet also advocates for defining clean and dirty areas, based on green, yellow, and red areas, with basic cleaning actions for non-disposable PPE and measures for handling disposable materials ${ }^{20}$.

In addition, based on the data from $\operatorname{Kampf}(2020)^{8}$, solutions of ethanol (78-95\%), 2-propranolol 45\%, in combination with 1-propanolol 30\%, glutaraldehyde (0.5-2.5\%), formaldehyde (0.7-1\%), and povidone-iodine (0.23-7.5\%) were the most effective agents for antisepsis, with a reduction of the viral $\operatorname{load}_{\text {of }} 4 \log _{10}$ or more, i.e., above the value recommended by the American and European authorities.

For the disinfection of rooms, patient waiting areas, surgical centers, and all common areas of hospitals, outpatient clinics, and other clinics, we suggest using pressurized backpack sprayers to massively apply sodium hypochlorite solutions at 0.1-0.5\%, between 100 and $300 \mathrm{ml}$ per $\mathrm{m}^{2}$, and in open areas (CCDCP, $2020)^{21}$, since this has been proven to be greatly effective against the coronavirus, in addition to being very accessible. 
According to a technical note published by the Brazilian Health Regulatory Agency (Anvisa), common household disinfectants, including water and soap or a solution of diluted bleach can deactivate the novel coronavirus on surfaces. This is due, mainly, to the fact that these disinfectants destroy the lipid layer that surrounds the coronavíruses ${ }^{22}$.

In addition, the note also informs about alternatives to alcohol $70 \%$ that cannot be used to disinfect objects and surfaces, including sodium hypochlorite $0.1 \%$, bleaches containing hypochlorite (sodium or calcium) $0.1 \%$, povidone-iodine $1 \%$, hydrogen peroxide $0.5 \%$, peracetic acid $0.5 \%$, benzalkonium chloride $0.05 \%$, phenolic compounds, and disinfectants for general use approved by Anvisa.

In a decision published on 17 March of this year ${ }^{23}$, Anvisa exceptionally authorized the selling of chlorhexidine digluconate $0.5 \%$, provided it is prepared according to the guidelines of the $2^{\text {nd }}$ edition, Revision 2, of the Brazilian Pharmacopoeia National Form ${ }^{24}$, which recommends adding other components to chlorhexidine, including isopropyl alcohol, benzalkonium chloride, polysorbate, lactic acid, and purified water. It is worth mentioning that, alone, chlorhexidine, as well as benzalkonium chloride, are not effective against the coronavirus ${ }^{8}$.

According to these data, it is suggested that chlorhexidine at the usual concentrations of $0.5 \%$ and $2 \%$ marketed in Brasil, alone or associated with cetrimide or alcohol at less than $70 \%$, is completely ineffective against the novel coronavirus ${ }^{8}$, putting healthcare professionals at a greater chance of contamination.

\section{CONCLUSION}

According to the data found in the literature, chlorhexidine is ineffective for the disinfection of surfaces containing coronavirus subtypes, which leads us to believe that it is also ineffective against the novel coronavirus. These data lead to a great concern regarding the spread of the novel coronavirus among health professionals, in particular physicians and nurses and other life and order maintenance agents since chlorhexidine is widely used in surgical and invasive procedures in ICUs, particularly in view of the great resistance of the novel coronavirus on surfaces such as plastic, face shields, latex gloves, masks, and disposable aprons.

Therefore, the use of other disinfectant agents is recommended, among them alcohol $70 \%$, sodium hypochlorite $0.1 \%$, bleach containing hypochlorite (sodium or calcium) $0.1 \%$, povidone-iodine $1 \%$, which have proved to be more effective. In addition, we suggest the completion of studies to prove the effectiveness of the disinfecting agents listed in the paper against the novel coronavirus, Sars-CoV-2, in view of its high degree of dissemination and the absence of studies related to this type of virus.

\section{Acknowledgments}

We would like to thank the Must University for their support.

\section{Author's Contribution}

Marcelo Souza de Assis, Angela Maria Moed Lopes - Definition of the theme and data collection, tabulation, data analysis, and creation of tables and figures.

Marcelo Souza de Assis, Angela Maria Moed Lopes, Renata Alves de Andrade Moreira Araújo - Drafting of the text and adjustments according to the standards of the periodical.

Angela Maria Moed Lopes, Renata Alves de Andrade Moreira Araújo - Revision of the text and adding of significant parts.

\section{RESUMO}

Um dado alarmante revelado por publicações a respeito dos agentes desinfetantes: o digluconato de clorexidina é ineficaz para desinfecção de superfícies contaminadas por coronavírus. Trata-se de uma constatação que reclama imediata divulgação, uma vez que essa substância é amplamente usada para degermação de mãos e antebraços dos cirurgiões e auxiliares e na antissepsia dos pacientes, em procedimentos minimamente invasivos, comumente em ambientes hospitalares. O objetivo deste trabalho foi comparar os diferentes desinfetantes usados para desinfecção em diversas superfícies em revisão de trabalhos mundiais. Foram pesquisados trabalhos científicos na BVS (Biblioteca Virtual de Saúde), PubMed, Medline e Anvisa (Agência Nacional de Vigilância Sanitária). Foram estudados os seguintes agentes: álcool 62-71\%, peróxido de hidrogênio 0,5\%, hipoclorito de sódio 0,1\%, cloreto de benzancônio 0,05-0,2\%, iodo povidina $10 \%$ e digluconato de clorexidina 0,02\%, em superfícies de metal, alumínio, madeira, papel, vidro, plástico, PVC, silicone, látex (luvas), avental descartável, cerâmica e teflon. Os estudos demonstraram que o digluconato de clorexidina é ineficaz para a inativação de alguns subtipos de coronavírus, sugerindo que também seja ineficaz contra o novo coronavírus. 


\section{REFERENCES}

1. Lai CC, Shih TP, Ko WC, Tang HJ, Hsueh PR. Severe acute respiratory syndrome coronavirus 2 (SARS-CoV-2) and coronavirus disease-2019 (COVID-19): The epidemic and the challenges. Int I Antimicrob Agents. 2020;55(3):105924. doi:10.1016/j.ijantimicag.2020.105924

2. Organização Mundial da Saúde (OMS). Novo coronavírus (2019-nCoV). Relatório de situação. https://www.who.int/docs/default-source/coronaviruse/situation-reports/20200528-COVID-19-sitrep-29.pdf?sfvrsn=5b154880_2 [acessado em 29 de maio de 2020].

3. United Nations Industrial Development Organization (UNIDO). Coronovírus - O impacto econômico. https://www.unido.org/stories/ coronavirus-economic-impact.

4. He CQ, He M, He HB, Wang HM, Ding NZ. The matrix segment of the "Spanish flu" virus originated from intragenic recombination between avian and human influenza A viruses. Transbound Emerg Dis. 2019;66(5):21882195. doi:10.1111/tbed.13282.

5. Alfani G, Murphy TE. Plague and Lethal Epidemics in the Pre-Industrial World. The Journal of Economic History. 2017;77(1):314-343. doi:10.1017/ S0022050717000092.

6. Decaro N, Lorusso A. Novel human coronavirus (SARS-CoV-2): A lesson from animal coronaviruses. Vet Microbiol. 2020;244:108693. doi:10.1016/j. vetmic.2020.108693.

7. Acter T, Uddin N, Das |, Akhter A, Choudhury TR, Kim S. Evolution of severe acute respiratory syndrome coronavirus 2 (SARS-CoV-2) as coronavirus disease 2019 (COVID-19) pandemic: A global health emergency [published online ahead of print, 2020 Apr 30]. Sci Total Environ. 2020;730:138996. doi:10.1016/j.scitotenv.2020.138996.

8. Kampf G, Todt D, Pfaender S, Steinmann E. Persistence of coronaviruses on inanimate surfaces and their inactivation with biocidal agents. / Hosp Infect. 2020;104(3):246-251. doi:10.1016/j.jhin.2020.01.022.

9. Moriya T, Modena L P. Assepsia e antissepsia: técnicas de esterilização. Medicina (Ribeirão Preto) 2008; 41 (3): 265-73. doi: 10.11606/issn.2176-7262

10. Yang Y, Peng F, Wang R, et al. The deadly coronaviruses: The 2003 SARS pandemic and the 2020 novel coronavirus epidemic in China [published correction appears in J Autoimmun. 2020 May 15; 102487]. J Autoimmun. 2020;109:102434. doi:10.1016/j.jaut.2020.102434

11. Yoshimoto FK. The Proteins of Severe Acute Respiratory Syndrome Coronavirus-2 (SARS CoV-2 or n-COV19), the Cause of COVID-19 [published online ahead of print, 2020 May 23]. Protein J. 2020;1-19. doi:10.1007/ s10930-020-09901-4

12. Tay MZ, Poh CM, Rénia L, MacAry PA, Ng LFP. The trinity of COVID-19: immunity, inflammation and intervention [published online ahead of print, 2020 Apr 28]. Nat Rev Immunol. 2020;1-12. doi:10.1038/s41577-020-0311-8
13. Van Doremalen N, Bushmaker T, Morris DH, et al. Aerosol and Surface Stability of SARS-CoV-2 as Compared with SARS-CoV-1. N Engl I Med. 2020;382(16):1564-1567. doi:10.1056/NEJMc2004973

14. Geller C, Varbanov M, Duval RE. Coronavírus humanos: insights sobre a resistência ambiental e sua influência no desenvolvimento de novas estratégias anti-sépticas. Vírus. 2012; 4 (11): 3044-3068. Publicado em 2012. 12. Nov. Doi: 10.3390 / v4113044

15. Sattar SA, Springthorpe VS, Karim Y, Loro P. Chemical disinfection of non-porous inanimate surfaces experimentally contaminated with four human pathogenic viruses. Epidemiol Infect. 1989;102(3):493-505. doi:10.1017/s0950268800030211

16. Chiewchalermsri $C$, Sompornrattanaphan $M$, Wongsa $C$, Thongngarm $T$. Chlorhexidine Allergy: Current Challenges and Future Prospects. J Asthma Allergy. 2020;13:127-133. Published 2020 Mar 9. doi:10.2147/JAA.S207980

17. Colares A 2015. Clorexidine indicação para uso em serviços de saúde [tese]. São Paulo: Faculdade Método de São Paulo; 2015.

18. Koh D. Occupational risks for COVID-19 infection. Occup Med (Lond) 2020;70(1):3-5. doi:10.1093/occmed/kqaa036

19. Conselho Federal de Enfermagem (COFEN). Cofen registra 10 mil casos de COVID-19 entre profissionais de enfermagem. http://www.cofen. gov.br/cofen-publica-observatorio-diario-da-COVID-19-entre-profissionais-de-enfermagem_79551.html.

20. Conselho Regiona de Farmácia de Minas Gerais (CRFMG). CORONAVÍRUS. PADM - Protocolo de Antissepsia e Desinfecção Massiva frente ao n-CoV-2. https://www.crfmg.org.br/site/uploads/areaTecnica/20200427[164659] coronaviruscartilhaPADM27042020.pdf

21. Chinese Center for Disease Control and Prevention. Handbook of COVID-19 Prevention and Treatment. https://irp-cdn.multiscreensite.com/a3b631e7/ files/uploaded/02.\%20Handbook\%20of\%20COVID-19\%20Prevention\%20and\%20Treatment.pdf.pdf

22. Agência Nacional de Vigilância Sanitária (ANVISA). Nota técnica no 47/2020/SEI/COSAN/GHCOS/DIRE3/ANVISA. Processo no. 25351.911971/2020-80. http://portal.anvisa.gov.

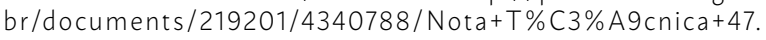
pdf/242a3365-2dbb-4b58-bfa8-64b4c9e5d863

23. Agência Nacional de Vigilância Sanitária (ANVISA). RESOLUÇÃO - RDC No 347, DE 17 DE MARÇO DE 2020. http://www.in.gov.br/web/dou/-/ resolucao-rdc-n-347-de-17-de-marco-de-2020-*-250404851

24. Agência de Vigilância Sanitária (ANVISA). Formulário Nacional de Farmacopeia Brasileira, $2^{\circ}$ Edição, Revisão 2. http://portal.anvisa.gov.br/documents/33832/259372/FNFB+2_Revisao_2_COFAR_setembro_2012_atual. pdf/20eb2969-57a9-46e2-8c3b-6d79dccf0741 